\title{
First record of Calycuoniscus goeldii (Lemos de Castro, 1967) (Oniscidea: Dubioniscidae) for the state of Piauí, northeastern Brazil
}

\author{
Vanderley Ferreira Silva Costa ${ }^{1}$, Daniela Correia Grangeiro ${ }^{1,2} \&$ Carlos Anderson \\ Soares Bezerra Pereira ${ }^{1}$
}

(1) Universidade Estadual do Piauí - Campus Professor Barros Araújo, Av. Senador Helvídio Nunes de Barros Junco, Picos 64600000, Piauí, Brazil. E-mail: yderley@gmail.com

(2) Universidade Federal da Paraíba - Campus I, Centro de Ciências Exatas e da Natureza, Departamento de Sistemática e Ecologia, Programa de Pós-Graduação em Ciências Biológicas (Zoologia), Cidade Universitária 58051-900, João Pessoa, Paraíba, Brazil. E-mail: daniela.grangeiro@gmail.com

Costa V.F.S., Grangeiro D.C. \& Pereira C.A.S.B. (2018) First record of Calycuoniscus goeldii (Lemos de Castro, 1967) (Oniscidea: Dubioniscidae) for the state of Piauí, northeastern Brazil. Pesquisa e Ensino em Ciências Exatas e da Natureza, 2(2): 152-157. http://dx.doi.org/10.29215/pecen.v2i2.1069

Academic editor: Flavio A. Alves-Jr. Received: 23 October 2018. Accepted: 28 November 2018. Published: 28 December 2018.

Primeiro registro de Calycuoniscus goeldii (Lemos de Castro, 1967) (Oniscidea, Dubioniscidae) para o Estado do Piauí, Nordeste do Brasil

Resumo: O presente trabalho fornece o primeiro registro de Calycuoniscus goeldii (Lemos de Castro, 1967) para o município de Picos, estado do Piauí, nordeste do Brasil. Além disso, este trabalho contribui para ampliar o conhecimento sobre a biodiversidade de isópodes terrestres do estado do Piauí e distribuição da família Dubioniscidae no Nordeste do Brasil.

Palavras-chave: Crustacea, Isopoda, novo registro, Picos.

Abstract: The present work provides the first record of Calycuoniscus goeldii (Lemos de Castro, 1967) from the municipality of Picos, state of Piauí, northeastern Brazil. In addition, this paper contributes to increase the knowledge about the biodiversity of terrestrial isopods of the state of Piauí and distribution of the family Dubioniscidae in northeastern Brazil.

Key words: Crustacea, Isopoda, new record, Picos.

\section{Introduction}

Isopods of the suborder Oniscidea Latreille, 1802 include most terrestrial species (Schmidt 2008). This group consists of about 3.710 species belonging to 38 families and 527 genera (Schmalfuss 2003; Sfenthourakis \& Taiti 2015). Most members of the suborder are small to medium in size, with species distributed worldwide from desert regions to forests, including habitats such as meadows, agroecosystems, mountains and caves (Hopkin \& Martin 1984).

Members of the Oniscidea have a relevant ecological role in terrestrial ecosystems since they feed on organic matter contributing to the nutrient cycling deposited in the soil as fecal pellets and in the formation of humus (Quadros \& Araújo 2008).

There are about 180 species of Recent terrestrial isopods in Brazil (Souza-Kury 1998; Schmalfuss 2003; Souza \& Grangeiro 2006; Grangeiro et al. 2014; Campos-Filho et al. 2014, 2015; 
Cardoso et al. 2016; Campos-Filho et al. 2018). Oniscidea from the family Dubioniscidae Schultz, 1995 are widely distributed in South America mainly in Venezuela, Trindade, Guyana and Brazil (between the northern to southeastern of the country), Paraguay and Argentina. Dubioniscidae includes the following genera: Dubioniscus Vandel, 1963; Calycuoniscus Collinge, 1915; and Novamundoniscus Schultz, 1995 (Lemos de Castro 1967, 1968; Souza-Kury 1998; Schmalfuss 2003; Campos-Filho et al. 2014; Grangeiro et al. 2014). The family is characterized by the presence of bristles on the dorsal region, cephalothorax with central-frontal depression and welldeveloped lateral lobes, antenna of three articles, pleon as wide as the pereon with well developed neopleurae, male and female with exopods of pleopods having similar shape (without respiratory structures) and exopods of the uropods surpassing the size of the pleotelson (Schultz 1995). Schmidt (2003) states that all characters attributed to Dubioniscidae are plesiomorphic or ambiguous and that the family may be paraphyletic.

The biological and ecological knowledge of Oniscidea from northeastern Brazil is still very incipient. The state of Piauí is one of the regions in the northeast of the country in which the group was little studied with only the records of the following families: Porcellionidae Brandt \& Ratzerburg, 1831; Platyarthridae Verhoeff, 1949; Armadillidae Brandt \& Ratzerburg, 1831; and Dubioniscidae Schultz, 1995 (Grangeiro et al. 2014).

This study provides the first record of Calycuoniscus goeldii (Lemos de Castro, 1967) for the state of Piauí, northeastern Brazil.

\section{Material and Methods}

\section{Study area}

The specimens examined in this study were collected between 2013 and 2017 in the vicinity of the Conduru and Junco neighborhood, both located in the municipality of Picos, state of Piauí, northeastern Brazil (Figure 1). The municipality is located in agricultural production systems of the state of Piauí, located $310 \mathrm{~km}$ from Teresina (Sousa 2012).

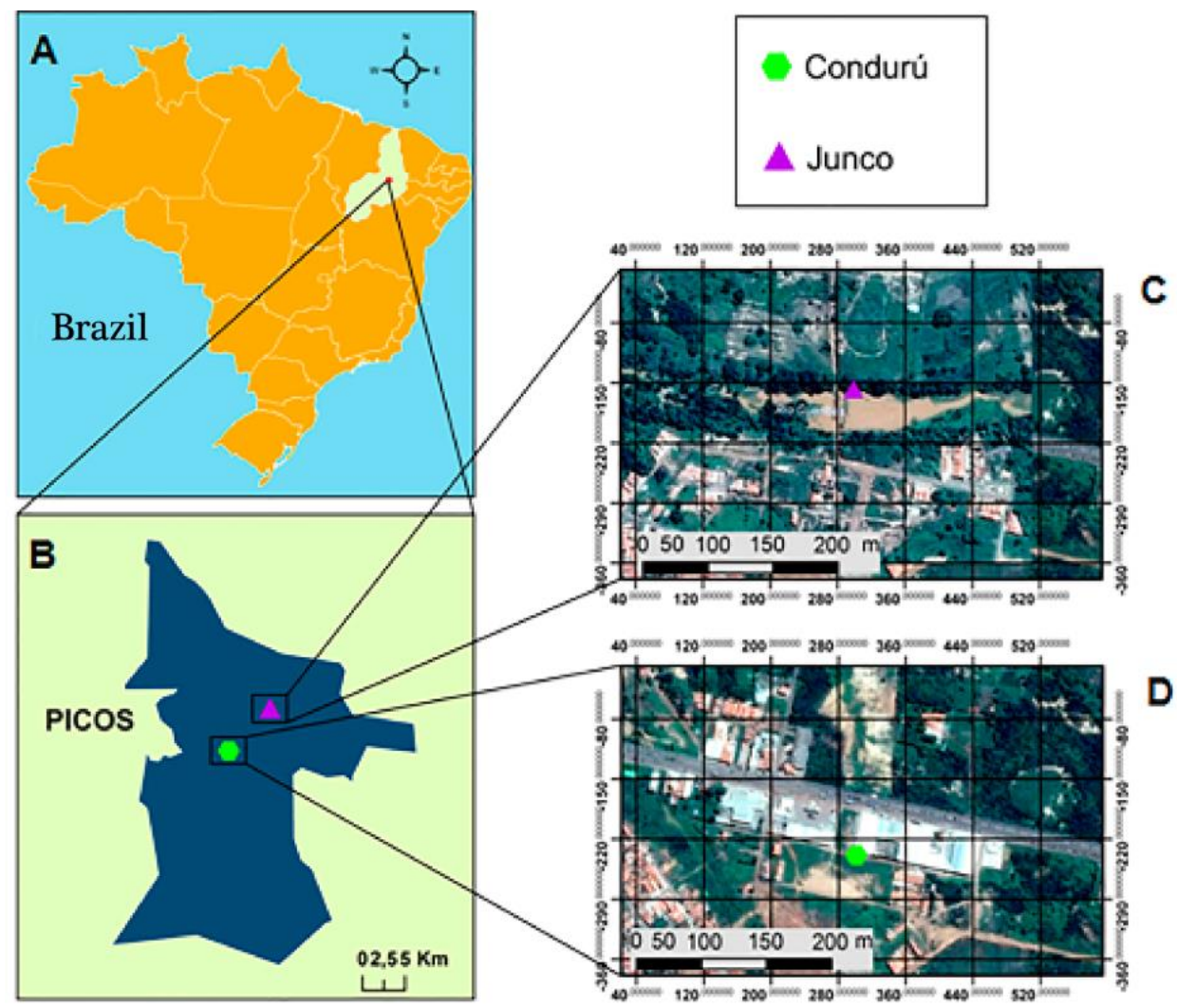

Figure 1. (A) Map of Brazil highlighting the state of Piauí; (B) Map of the city of Picos showing the neighborhoods of Conduru and Junco; (C) Collection area in the neighborhood of Junco (purple triangle - sampling site); (D) Collection area in the neighborhood of Condurú (green pentagon - sampling site). 


\title{
Sampling, sorting and identification
}

The samples were carried out through active search by members of the Grupo de Estudos Taxonômicos dos Oniscidea do Piauí (GETOPI). Specimens were stored in ethanol $70 \%$ and deposited in the Laboratório de Biologia da Universidade Estadual do Piauí (UESPI), Campus Professor Barros Araújo, Picos, Piauí. All specimens were analyzed under stereomicroscope with the aid of brushes, tweezers and petri dishes. The identification was performed based on Lemos de Castro (1967, 1968) and Schultz (1995) with aid of stereomicroscope and optical microscope through the morphological analysis of the habitus, antenna and pereopods of individuals. The material analyzed is deposited and available for study at the "Universidade Estadual do Piauí (UESPI)", Picos, Piauí and "Coleção de Invertebrados Paulo Young, Departamento de Sistemática e Ecologia, Universidade Federal da Paraíba (UFPB)", João Pessoa, Paraíba, Brazil”.

\section{Results}

\author{
Isopoda Latreille, 1817 \\ Oniscidea Latreille, 1803 \\ Dubioniscidae Schultz, 1995 \\ Calycuoniscus Collinge, 1915
}

Type species: Calycuoniscus bodkini Collinge, 1915 by monotypy.

\section{Calycuoniscus goeldii (Lemos de Castro, 1967)}

Figures 2-3

Hileioniscus goeldii Lemos de Castro 1967: 318.

Calycuoniscus goeldii - Lemos de Castro (1968: 409, figs 1-7); Cardoso et al. (2016: 3).

Dubioniscus goeldii - Schultz (1995: 400).

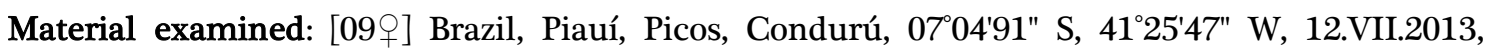

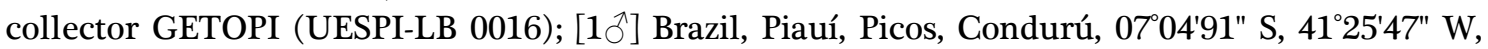
12.VII.2013, collector GETOPI (UESPI-LB 0018); [1 q] Brazil, Piauí, Picos, Condurú, 07 04'91" S, $41^{\circ} 25^{\prime} 47^{\prime \prime}$ W, 26-IX-2015, collector GETOPI (UESPI-LB 0071); [2ᄋ] Brazil, Piauí, Picos, Condurú, 07 04'91" S, 4125'47" W, 30.X.2015, collector GETOPI (UESPI-LB 0091); [5ㅇ] Brazil, Piauí, Picos, Junco, 07 04'44" S, 4126'33" W, 02.X.2016, collector GETOPI (UESPI-LB 0093); [2이 Brazil, Piauí,

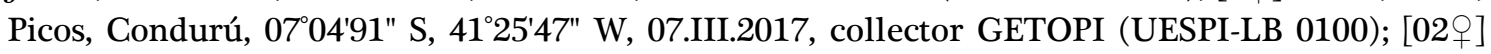
Brazil, Piauí, Picos, Condurú, 0704'91" S, 41²5'47" W, 12.VII.2013, collector GETOPI (UFPB).

Diagnosis: Specimens having $5 \mathrm{~mm}$ in maximum length. Brown color with light spots and continuous light longitudinal bands between median line and lateral margins of pereonites and pleon. Tegument covered by scaly setae. Cephalothorax without frontal depression, with triangular-shaped medial and lateral lobes with straight sides. Antenna having three articles with thin suture between second and third. Male with exopod of pleopode 1 oval and widened distal part; endopod with distal end having row of small spines. Male with exopod of pleopode 2 triangular. Uropod exopods surpassing telson; endopods not visible in dorsal view.

Geographic distribution: BRAZIL - Pará (Lemos de Castro 1967, 1968; Souza-Kury 1998; Leistikow \& Wägele 1999; Schmalfuss 2003), Piauí (Picos) (present study), Chapada do Araripe (Crato-Ceará) (Souza \& Grangeiro 2006) (Figure 1).

Remarks: The individuals of Calycuoniscus goeldii were recognized here mainly based on antenna with thin suture between the second and third articles (Figure 3), bristles of habitus 
directed backwards, brown color with light spots (Figure 2) and cephalothorax with median and lateral lobes with triangular shape and straight sides.

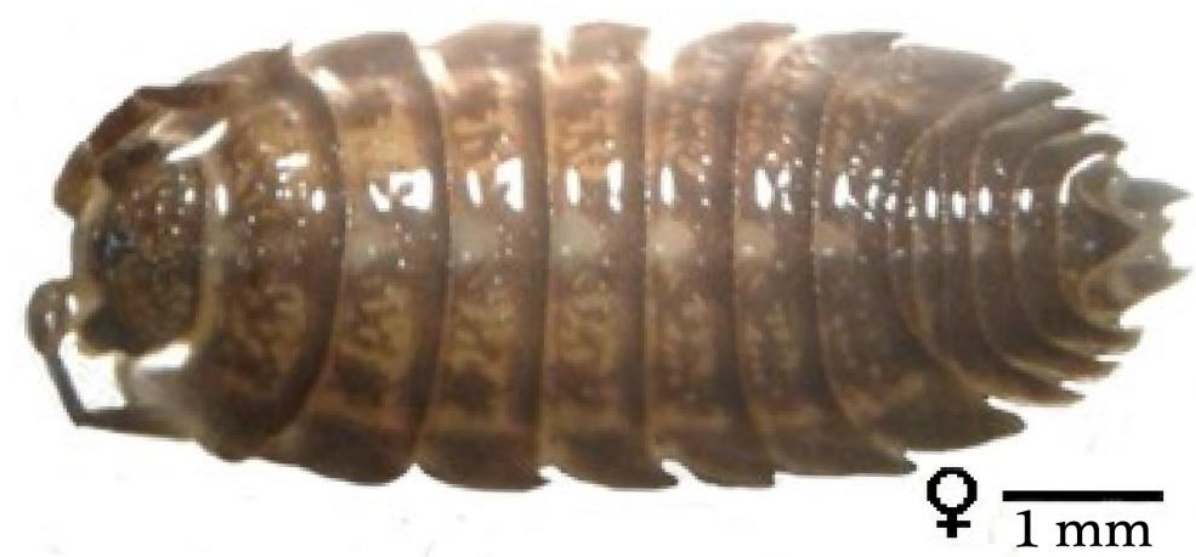

Figure 2. Habitus of female individual of Calycuoniscus goeldii collected in the state of Piauí (Picos), northeastern Brazil.

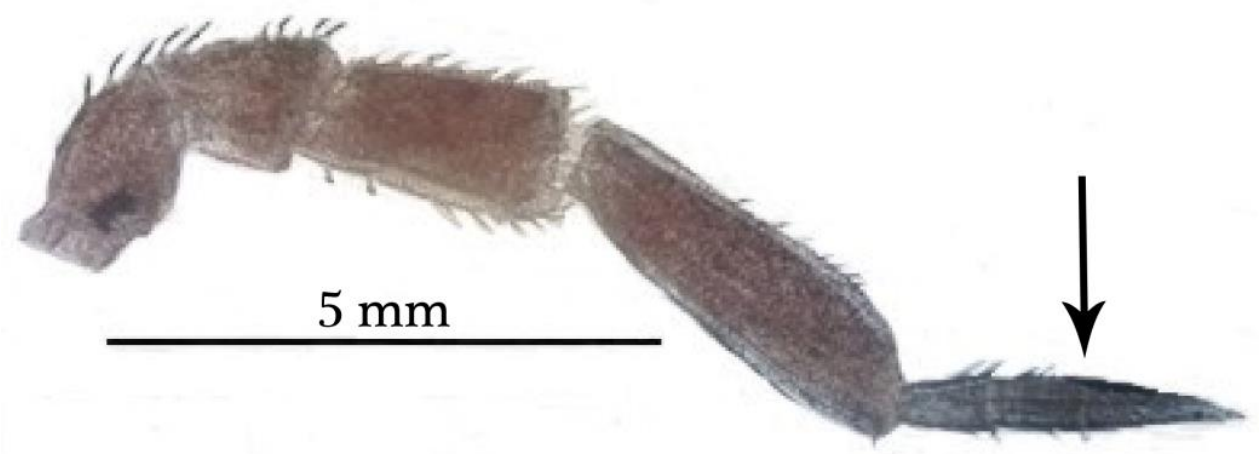

Figure 3. Antenna with thin suture between the second and third articles of female individual of Calycuoniscus goeldii collected in the state of Piauí (Picos), northeastern Brazil.

\section{Discussion}

Members of the genera Dubioniscus and Calycuoniscus are similar in general morphology and antenna with thin suture between the second and third articles in an approximately bi-flagellated condition. Furthemore, Dubioniscus has a V-shape anterodorsal depression in the cephalothorax (Schultz 1995), which is absent in individuals of the genera Calycuoniscus and Novamundoniscus (Cardoso et al. 2016).

To date, only four species of the genus Calycuoniscus are known: C. ambiguus (BuddeLund, 1893), C. compar (Budde-Lund, 1893) [Venezuela], C. bodkini Collinge, 1915 [Trindade, Guiana and Brazil] and C. spinosus Collinge, 1917 [Trindade (West Indies)] (Schultz 1995). There are now two species of this genus with occurrences in Brazil: C. bodkini Collinge, 1915 recorded from Amazon rainforest (Schmalfuss 2003) and C. goeldii Lemos de Castro, 1967 recorded from the states of Pará and Ceará (Schmalfuss 2003; Souza \& Grangeiro 2006).

Calycuoniscus goeldii is recorded from cascade region of the Batateiras river, Chapada do Araripe, state of Ceará, northeastern Brazil (Souza \& Grangeiro 2006). This study represents the first record of C. goeldii from the state of Piauí and it contributes to expand the knowledge on the species richness in the region and the geographic distribution of taxa belonging to the family Dubioniscidae in northeastern Brazil. 


\section{Acknowledgments}

The authors are grateful to M. Sc. Rudá Amorim Lucena (UFPB/CCEN/DSE) and the anonymous reviewers for their precious comments on the paper.

\section{References}

Campos-Filho I.S., Araujo P.B., Bichuette M.E., Trajano E. \& Taiti S. (2014) Terrestrial isopods (Crustacea: Isopoda: Oniscidea) from Brazilian caves. Zoological Journal of the Linnean Society, 172(2): 360-425. DOI: 10.1111/zoj.12172

Campos-Filho I.S., Mise K.M. \& Sessegolo G.C. (2015) A new species of Trichorhina Budde-Lund, 1908 (Isopoda: Oniscidea: Platyarthridae) from Paraná caves, southern Brazil. Nauplius, 23(2): 112-119. DOI: 10.1590/S0104-64972015002324

Campos-Filho I.S., Lisboa J.T. \& Cardoso G.M. (2018) A new genus and two new species of Pudeoniscidae Lemos de Castro 1973 (Crustacea: Isopoda: Oniscidea) from Brazil. Journal of Natural History, 52(7-8): 457-482, DOI: 10.1080/00222933.2018.1437229.

Cardoso G.M., Campos-Filho I.S. \& Araujo P.B. (2016) The genus Dubioniscus Vandel, 1963 (Oniscidea, Dubioniscidae) with descriptions of two new species from Brazil. Tropical Zoology, 29: 111-133. DOI: 10.1080/03946975.2016.1179024

Grangeiro D.C., Borges N.R.S. \& Moura G.I.B.S.C. (2014) Primeiro registro de Crustáceos Terrestres (Isopoda, Oniscidea) para o Piauí, Brasil. (p. 89-101). In: Grangeiro D.C., Azar G.S. \& Pessoa W.R.L.S. (Orgs). Pesquisas no Semiárido Piauiense. Curitiba: CRV. 204 p.

Hopkin S.P. \& Martin M.H. (1984) Heavy metals in woodlice (p. 143-166). In: Sutton S.L. \& Holdich D.M. (Eds). The Biology of Terrestrial Isopods. The Zoological Society of London. Number 53. Oxford: Clarendon Press. 518 p.

Leistikow A. \& Wägele J. (1999) Checklist of the terrestrial isopods of the new world (Crustacea, Isopoda, Oniscidea). Revista Brasileira de Zoologia, 16: 1-72. DOI: 10.1590/S010181751999000100001

Lemos de Castro A. (1967) Isópodos terrestres da Amazônia Brasileira (Isopoda, Oniscoidea). Atas do Simpósio sobre a Biota Amazônica, 5: 311-336.

Lemos de Castro A. (1968) Descrição complementar de Calycuoniscus goeldii (Lemos de Castro) (Isopoda Terrestria, Oniscidae, Bathytropinae). Revista Brasileira de Biologia, 28(4): 407-412.

Quadros A.F. \& Araújo P.B. (2008) An assemblage of terrestrial isopods (Crustacea) in southern Brazil and its contribution to leaf litter processing. Revista Brasileira de Zoologia 25(1): 58-66. DOI: 10.1590/S0101-81752008000100009

Schmalfuss H. (2003) World catalog of terrestrial isopods (Isopoda: Oniscidea). Stuttgater Beiträge zur Naturkunde, 654: 1-341.

Schmidt C. (2003) Contribution to the phylogenetic system of the Crinocheta (Crustacea, Isopoda). Part 2. (Oniscoidea to Armadillidiidae). Mitteilungen aus dem Museum für Naturkunde in Berlin, Zoologische Reihe, 79: 3-179. DOI: 10.1002/mmnz.4850790102

Schmidt C. (2008) Phylogeny of the Terrestrial Isopoda (Oniscidea): a Review. Arthropod Systematics \& Phylogeny, 66(2): 191-226.

Schultz G.A. (1995) Terrestrial isopod crustaceans (Oniscidea) from Paraguay with definition of a new family. Revue Suisse de Zoologie, 102: 387-424.

Sfenthourakis S. \& Taiti S. (2015) Patterns of taxonomic diversity among terrestrial isopods. ZooKeys, 515: 13-25. DOI: 10.3897/zookeys.515.9332

Sousa M.D. (2012) Identidade e docência: o saber-fazer do professor e de Sociologia das escolas públicas estaduais de Picos/PI. Tese, Programa de Pós-Graduação em Educação, Universidade Federal do Rio Grande do Norte, Natal.

Souza L.A. \& Grangeiro D.C. (2006) Primeiro registro de crustáceos terrestres (Isopoda, Oniscidea) para a Chapada do Araripe, Ceará, Brasil. Cadernos de Cultura e Ciência, 1(1): 3339. 
Souza-Kury L.A. (1998) Malacostraca - Peracarida. Isopoda. Oniscidea (p. 653-674). In: Young P.S. (Ed.). Catalogue of Crustacea of Brazil. Rio de Janeiro: Museu Nacional. 717 p. 